\title{
PENGARUH PENGGUNAAN MEDIA PEMBELAJARAN AUDIO VISUAL TIPE VIDEO TERHADAP HASIL BELAJAR SISWA PADA MATA PELAJARAN AKUNTANSI DASAR KELAS X PBKM DI SMK NEGERI 2 BANJAR
}

\author{
Ani Lutfianingrum ${ }^{1}$, Utti Suwirta², Dedeh ${ }^{3}$ \\ 1,2,3 Program Studi Pendidikan Akuntansi, Universitas Galuh, JI. R. E. Martadinata No. 150, Ciamis, indonesia \\ Email: lutfianingrum98@gmail.com
}

\begin{abstract}
This research is based on the low student learning outcomes caused by the focus of learning on educators which causes students to be less active in the learning process and also the lack of use of fun learning media. One of the efforts that can be made to improve student learning outcomes is through the use of video-type audio-visual learning media. The purpose of this study was to determine: 1) The improvement of student learning outcomes in classes using Audio Visual Media Types of Video in the initial (pretest) and final (post-test) measurements. 2) Improved student learning outcomes in classes using conventional learning methods at the initial (pretest) and final (post-test) measurements. 3) The difference in student learning outcomes using the Audio Visual Type of Video Media with those using conventional methods in the final measurement (post-test). The method used in this research is a quasi-experimental method (Quasi Experimental). This study resulted in the following conclusions: 1) There was an increase in student learning outcomes in classes using Audio Visual Media Types of Video in the initial (pretest) and final (post-test) measurements. 2) There is an increase in student learning outcomes in classes using conventional learning methods at the initial (pretest) and final (post-test) measurements. 3) There are differences in student learning outcomes using the Audio Visual Type of Video Media with those using conventional methods in the final measurement (post-test).
\end{abstract}

Keywords: Video type audio-visual learning media, learning outcomes.

\begin{abstract}
ABSTRAK
Penelitian ini di latar belakangi oleh rendahnya hasil belajar siswa yang disebabkan oleh terpusatnya pembelajaran pada pendidik yang menyebabkan kurang aktifnya siswa dalam proses pembelajaran dan juga kurangnya penggunaan media pembelajaran yang menyenangkan. Salah satu upaya yang dapat dilakukan untuk meningkatkan hasil belajar siswa yaitu melalui penggunaan media pembelajaran audio visual tipe video. Tujuan penelitian ini adalah untuk mengetahui: 1) Peningkatan hasil belajar siswa pada kelas yang menggunakan Media Audio Visual Jenis Video pada pengukuran awal (pretest) dan akhir (post-test). 2) Peningkatan hasil belajar siswa pada kelas yang menggunakan Metode pembelajaran konvensional pada pengukuran awal (pretest) dan akhir (post-test). 3) Perbedaan hasil belajar siswa yang menggunakan Media Audio Visual Jenis Video dengan yang menggunakan metode konvensional pada pengukuran akhir (post-test). Metode yang digunakan dalam penelitian ini adalah metode kuasi eksperimen (Quasi Eksperimental). Penelitian ini menghasilkan simpulan sebagai berikut: 1) Terdapat peningkatan hasil belajar siswa pada kelas yang menggunakan Media Audio Visual Jenis Video pada pengukuran awal (pretest) dan akhir (post-test). 2) Terdapat peningkatan hasil belajar siswa pada kelas yang menggunakan Metode pembelajaran konvensional pada pengukuran awal (pretest) dan akhir (post-test). 3) Terdapat perbedaan hasil belajar siswa yang menggunakan Media Audio Visual Jenis Video dengan yang menggunakan metode konvensional pada pengukuran akhir (post-test).
\end{abstract}

Kata kunci: media pembelajaran audio visual tipe video, hasil belajar.

Cara sitasi: Lutfianingrum A,. Suwirta., \& Dedeh. (2021). Pengaruh Penggunaan Media Audio Visual Tipe Video Terhadap Hasil Belajar Siswa Pada Mata Pelajaran Akuntansi Kelas X PBKM SMKN 2 Banjar. J-KIP (Jurnal Keguruan dan IImu Pendidikan), 2 (3), 61-68. 


\section{PENDAHULUAN}

Kegiatan pembelajaran di sekolah berfungsi untuk mencapai hasil belajar, dalam pendidikan hasil belajar merupakan hal penting dan menjadi tujuan utama. Hasil belajar merupakan salah satu indikator untuk melihat sejauh mana pencapaian kompetensi dasar dan standar kompetensi yang ditetapkan dalam kegiatan pembelajaran. Rendahnya hasil belajar siswa menjadi faktor kegagalan dari proses pembelajaran yang kurang efektif dan merupakan salah satu masalah yang harus segera diselesaikan untuk semua pihak sekolah baik itu antara guru dengan siswa.

Dimyati dan Mudjiono (2006) mengungkapkan "Hasil belajar adalah hasil dari suatu interaksi tindak belajar dan tindak mengajar. Dari sisi guru, tindak mengajar diakhiri dengan proses evaluasi hasil belajar. Dari sisi siswa, hasil belajar merupakan berakhirnya pengajaran dari puncak proses belajar". Sudjana (2009) mengungkapkan hasil belajar bahwa "Perubahan tingkah laku sebagai hasil belajar dalam pengertian yang lebih luas mencakup bidang kognitif, afektif, dan psikomotorik".

Slameto (2010) mengungkapkan "Faktor-faktor yang mempengaruhi hasil belajar dapat dibedakan menjadi 2 golongan yaitu: 1). Faktor yang ada pada diri siswa itu sendiri yang disebut faktor individu (intern); (a) Faktor Jasmaniah, meliputi: kesehatan, gizi, pendengaran dan penglihatan; (b) Faktor Psikologis, meliputi: intelegensi, minat dan motivasi serta perhatian ingatan berpikir, (c) Faktor kelelahan, meliputi: kelelahan jasmaniah dan rohani. Faktor yang ada pada luar individu yang disebut dengan faktor Ekstern, yang meliputi; (a) Faktor keluarga, keluarga adalah lembaga pendidikan yang pertama dan utama. (b) Faktor sekolah, meliputi; metode mengajar, kurikulum, hubungan guru dengan siswa, siswa dengan siswa dan berdisiplin di sekolah; (c) Faktor masyarakat, meliputi: bentuk kehidupan masyarakat sekitar dapat mempengaruhi prestasi siswa.

Pembelajaran yang terjadi di kelas idealnya adalah pembelajaran yang aktif dan menyenangkan, namun pada umumnya pembelajaran masih terpusat pada guru dan guru tidak menggunakan media pembelajaran yang menyenangkan. Pembelajaran yang terpusat pada guru dan penggunaan media pembelajaran yang kurang maksimal akan membuat siswa pasif dalam belajar dan cenderung menimbulkan kejenuhan. Hal tersebut berpotensi berpengaruh terhadap rendahnya hasil belajar siswa.Tinggi rendahnya hasil belajar siswa menentukan anggapan di masyarakat tentang kemampuan seorang siswa. Hasil belajar merupakan cerminan dari sikap dan perilaku siswa khususnya dari segi pengetahuannya.

Sebagai data awal, berikut ini diuraikan nilai rata-rata ulangan harian mata pelajaran Akuntansi Dasar sebagai berikut :

\section{Tabel 1. Rata-rata Nilai Ulangan Harian Mata Pelajaran Akuntansi Dasar Semester Ganjil Kelas X PBKM SMK Negeri 2 Banjar \\ Tahun Pelajaran 2020/2021}

\begin{tabular}{|c|c|c|c|c|c|c|c|c|c|c|}
\hline No & Kelas & $\begin{array}{c}\text { Jumlah } \\
\text { Siswa }\end{array}$ & KKM & $\begin{array}{c}\text { Nilai } \\
\text { terendah }\end{array}$ & $\begin{array}{c}\text { Nilai } \\
\text { tertinggi }\end{array}$ & $\begin{array}{c}\text { Nilai Rata- } \\
\text { rata UH }\end{array}$ & $\begin{array}{l}\text { Jun } \\
\text { yans }\end{array}$ & $\begin{array}{l}\text { Siswa } \\
\text { ncapai } \\
\end{array}$ & & $\begin{array}{l}\text { Siswa } \\
\text { ilum } \\
\text { i KKM }\end{array}$ \\
\hline 1 & X PBKM 1 & 36 & 75 & 61 & 84 & 71 & 16 & $44 \%$ & 20 & $56 \%$ \\
\hline 2 & X PBKM 2 & 36 & 75 & 54 & 83 & 70 & 15 & $42 \%$ & 21 & $58 \%$ \\
\hline 3 & X PBKM 3 & 27 & 75 & 60 & 85 & 72 & 11 & $41 \%$ & 16 & $59 \%$ \\
\hline
\end{tabular}

Berdasarkan tabel 1 dapat dilihat nilai KKM (Kriteria Ketentuan Minimal) Mata Pelajaran Akuntansi Dasar kelas X PBKM SMK Negeri 2 Banjar adalah 75. Dengan nilai siswa yang mencapai KKM berjumlah 42 orang siswa dari keseluruhan jumlah siswa yaitu 99 orang. Dari nilai siswa yang mencapai KKM tersebut, kelas X PBKM 1 merupakan kelas dengan jumlah nilai siswa yang mencapai KKM terbanyak sejumlah 15 orang atau 44\%, sedangkan untuk kelas dengan nilai siswa yang mencapai nilai KKM paling sedikit yaitu kelas X PBKM 3 dengan jumlah siswa sebayak 11 
orang atau $41 \%$. Dari tabel di atas juga, dapat dilihat nilai siswa yang belum mencapai KKM berjumlah 57 orang dari keseluruhan siswa 99 orang. Dari nilai siswa yang belum mencapai KKM tersebut, kelas X PBKM 2 merupakan kelas dengan jumlah nilai siswa yang belum mencapai KKM terbanyak dengan jumlah siswa 21 orang atau $58 \%$, sedangkan untuk kelas dengan nilai siswa yang belum mencapai KKM yang paling sedikit yaitu kelas X PBKM 3 dengan jumlah siswa 16 orang atau 59\%. Dari tabel 1 juga dapat dilihat nilai Mata Pelajaran Akuntansi Dasar tertinggi dikelas X PBKM SMK Negeri 2 Banjar adalah 85 dan nilai terendah 54. Dari data awal tersebut dapat diketahui bahwa nilai rata-rata ulangan harian yang dicapai oleh masing-masing kelas dapat disimpulkan belum optimal.

Salah satu masalah dalam pembelajaran yaitu lemahnya proses pembelajaran, dimana dalam proses pembelajaran tersebut siswa kurang didorong untuk mengembangkan kemampuan berpikir. Media pembelajaran merupakan salah satu yang berpengaruh terhadap hasil belajar siswa. Kegiatan pembelajaran di sekolah memerlukan media pendukung yang akan menunjang keberhasilan pencapaian tujuan pembelajaran. Media diharapkan dapat memudahkan siswa dalam menerima materi pembelajaran. Media dalam proses pembelajaran berperan penting, karena media merupakan komponen dalam kegiatan belajar mengajar yang digunakan atas dasar tujuan dan bahan pelajaran yang telah ditetapkan, oleh karena itu pendidik sebagai subyek pembelajaran harus dapat memilih media dan sumber belajar yang tepat, sehingga bahan pelajaran yang disampaikan dapat diterima peserta didik dengan baik (Gultom dalam Putri, Pajriah \& Kusmayadi, (2021). Slameto dalam Aryansyah (2021) menyatakan bahwa metode mengajar yang kurang baik akan mempengaruhi belajar siswa yang tidak baik pula. Sehingga siswa kurang senang terhadap pelajaran atau gurunya, akibatnya siswa malas untuk belajar.

Realita di lapangan pemanfaatan media masih kurang optimal khususnya dalam penggunaan media audio visual. Oleh karena itu guru harus menggunakan media yang dinilai efektif. Salah satunya adalah media pembelajaran audio visual tipe Video. Menurut Djamarah \& Zain (2013) "Media audio visual adalah media yang mempunyai unsur suara dan unsur gambar".

Setiap penelitian yang dilakukan tentunya mempunyai maksud dan tujuan yang ingin di capai oleh penulis. tujuan penelitian ini yaitu untuk mengetahui: 1) Peningkatan hasil belajar siswa pada kelas yang menggunakan Media Audio Visual Tipe Video pada pengukuran awal (pretest) dan akhir (post-test). 2) Peningkatan hasil belajar siswa pada kelas yang menggunakan Metode pembelajaran konvensional pada pengukuran awal (pretest) dan akhir (post-test). 3) Perbedaan hasil belajar siswa yang menggunakan Media Audio Visual Tipe Video dengan yang menggunakan metode konvensional pada pengukuran akhir (post-test).

Adapun kegunaan teoritis dari penelitian ini adalah Hasil penelitian ini diharapkan dapat memberikan kontribusi positif terhadap pengembangan pengetahuan khususnya yang berkaitan dengan penggunaan media pembelajaran audio visual tipe video. Sedangkan kegunaan praktis dari penelitian ini adalah 1) bagi sekolah, Memberikan masukan untuk dapat meningkatkan hasil belajar siswa dengan mencoba Media Audio Visual Tipe Video. 2) bagi guru, Dapat memberikan pengetahuan dan informasi serta sumbangan pemikiran tentang penerapan media yang bervariasi dan menyenangkan bagi siswa dalam meningkatkan hasil belajar. 3) bagi peneliti, Memberikan pengalaman serta pelatihan secara teknis untuk menerapkan teori yang di dapat selama perkuliahan dengan membandingkan secara langsung saat praktek di lapangan. 4) bagi siswa, Membantu siswa mengatasi kesulitan belajar dengan menemukan cara belajar yang menyenangkan dan tidak membosankan. 5) bagi pihak lain, dapat memberikan motivasi untuk mengembangkan dan melakukan penelitian lainnya. 


\section{METODE PENELITIAN}

Metode penelitian yang digunakan dalam penelitian ini adalah metode kuasi eksperimen (Quasi Eksperimental), yaitu metode yang digunakan peneliti untuk mencari pengaruh perlakuan tertentu terhadap yang lain, dalam penelitian ini tentunya untuk mencari pengaruh penggunaan media audio visual tipe video terhadap hasil belajar siswa.

Populasi pada penelitian ini yaitu seluruh siswa kelas X PBKM di SMK Negeri 2 Banjar yang terdiri dari 99 siswa.

Tabel 2. Populasi Siswa Kelas X PBKM SMK Negeri 2 Banjar

\begin{tabular}{cccc}
\hline Kelas & Laki-laki & Perempuan & Jumlah siswa \\
\hline XI PBKM1 & 8 & 28 & 36 \\
XI PBKM 2 & 9 & 27 & 36 \\
XI PBKM 3 & 7 & 20 & 27 \\
Jumlah & 23 & 76 & 99
\end{tabular}

Sedangkan dalam menentukan sampel pada penelitian ini menggunakan teknik purposive sampling yaitu teknik penentuan sampel melalui pertimbangan tertentu. Berdasarkan nilai rata rata pretest, dua kelas dinyatakan memiliki rata-rata nilai pretest hampir mendekati seimbang yaitu kelas $X$ PBKM 1 dan kelas X PBKM 2. Dan setelah dilakukan uji homogenitas kedua kelas tersebut dinyatakan homogen. Sehingga sampel pada penelitian ini yaitu kelas X PBKM 1 sebagai kelas eksperimen atau kelas yang diberi perlakuan media audio visual tipe video dan kelas X PBKM 2 sebagai kelas kontrol atau kelas yang menggunakan metode konvensinonal

Pada penelitian ini teknik pengumpulan data yang dilakukan yaitu dokumentasi, tes hasil belajar dan tes akhir/ posttest. Sedangkan teknis analisis data yang digunakan yaitu:

1. Uji Validitas

Untuk mengetahui valid atau shahih tidaknya suatu instrumen. Teknik yang digunakan untuk mengetahui validitas instrumen penelitian adalah dengan korelasi product moment

2. Uji Reliabilitas

Untuk mengetahui tingkat konsistensi suatu instrumen. Rumus yang akan digunakan untuk menguji realibilitas tes adalah rumus K-R 20.

3. Analisis Tingkat Kesukaran

Untuk mengetahui tingkat kesulitan instrumen. Rumus yang digunakan untuk menganalisis tingkat kesukaran adalah rumus proportion correct.

4. Analisis Daya Beda

Untuk mengukur instrumen sejauh mana mampu membedakan siswa yang suda mengusai dengan yang belum/kurang menguasai.

5. Analisis Data

Untuk mengetahui perbedaan hasil belajar siswa pada pengukuran awal (Pretest) dan pengukuran akhir (Postest) pada kelas eksperimen yaitu dengan menggunakan rumus N-Gain

\section{HASIL DAN PEMBAHASAN}

Peningkatan Hasil Belajar Siswa yang Menggunakan Media Audio Visual Jenis Video pada Pengukuran Awal (pretest) dan Pengukuran Akhir (posttest) pada Kelas Eksperimen

Berdasarkan hasil belajar siswa pada pengukuran awal (pretest) di kelas eksperimen ( $X$ PBKM 1) dengan jumlah 36 siswa, diperoleh hasil belajar dengan nilai tertinggi sebesar 75 dan nilai terendah sebesar 30 dengan nilai rata-rata sebesar 53,75. Sedangkan, setelah diberikan perlakuan dengan menggunakan media pembelajaran Audio Visual jenis Video pada pengukuran akhir (posttest) diperoleh nilai tertinggi sebesar 90 dan nilai terendah 75 dengan nilai rata-rata sebesar 
84,36. Peningkatan hasil belajar siswa dengan menggunakan media pembelajaran Audio Visual Tipe Video sebesar 23,20 dengan rata-rata 0,64 ini termasuk dalam kategori sedang.

Tabel 3. Kategori N-Gain Kelas Eksperimen (X PBKM 1) SMK Negeri 2 Banjar

\begin{tabular}{cc}
\hline Kategori & Frekuensi N-Gain \\
\hline Tinggi & 9 \\
Sedang & 27 \\
Rendah & - \\
Kategori rata-rata & 0,64 \\
Jumlah siswa & 36 \\
\hline
\end{tabular}

Dari 36 siswa yang memiliki kategori N-Gain tinggi berjumlah 9 orang dan kategori N-Gain sedang berjumlah 27 orang. Sehingga besarnya N-Gain peningkatan hasil belajar siswa kelas eksperimen (X PBKM 1) SMK Negeri 2 Banjar pada mata pelajaran akuntansi dasar dengan menggunakan media pembelajaran Audio Visual tipe Video setelah melaksanakan pretest dan posttest bernilai 23,20 dengan rata-rata 0,64 dan termasuk dalam kategori $\mathrm{N}-\mathrm{Gain}$ sedang atau berada pada interval $0,30<\mathrm{N}$-gain $<0,70$.

Peningkatan hasil belajar siswa terjadi karena melalui penggunaan media pembelajaran audio visual tipe video dapat merangsang siswa untuk aktif berperan serta dalam pembelajaran. Dengan media pembelajaran audio visual tipe video materi pembelajaran di suguhkan dalam bentuk audio (suara) dan visual (gambar). Sesuai dengan pendapat. Menurut Simarmata et al., (2020) mengungkapkan bahwa "Video merupakan seperangkat komponen atau media yang mampu menampilkan gambar sekaligus suara dalam waktu bersamaan".

Dengan penyajian materi dalam bentuk audio maka sangat cocok bagi siswa yang memiliki gaya belajar auditorial yaitu lebih menggunakan indera pendengarannya untuk dapat memahami materi pada saat pembelajaran. Selain itu, penyajian dalam bentuk visual juga sangat membantu siswa yang memiliki gaya belajar visual yaitu lebih menggunakan indera penglihatan untuk memahami materi pada saat pembelajaran.

Media pembelajaran audio visual tipe video mampu menarik antusias dari siswa untuk mengikuti proses pembelajaran. Antusias siswa ini timbul karena penyajian materi yang tidak membosankan sehingga muncul rasa menyenangkan yang memberikan efek semangat bagi siswa untuk mengikuti proses pembelajaran dan mempermudah siswa untuk menyerap materi yang diberikan sehingga mampu meningkatkan hasil belajar siswa.

\section{Peningkatan Hasil Belajar Siswa yang Menggunakan Metode Pembelajaran Konvensional pada Pengukuran Awal (pretest) dan Akhir (posttest) pada Kelas Kontrol}

Berdasarkan hasil belajar siswa pada pengukuran awal (pretest) di kelas kontrol (X PBKM 2) dengan jumlah 36 siswa, diperoleh hasil belajar dengan nilai tertinggi sebesar 75 dan nilai terendah sebesar 30 dengan nilai rata-rata sebesar 53,47. Sedangkan, pada pengukuran akhir (posttest) diperoleh nilai tertinggi sebesar 85 , nilai terendah 65 dan nilai rata-rata sebesar 76,25 . Peningkatan hasil belajar siswa yang menggunakan metode konvensional sebesar 17,71 dengan rata-rata 0,49 ini termasuk dalam kategori sedang. 
Tabel 4. Kategori N-Gain Kelas Kontrol (X PBKM 2) SMK Negeri 2 Banjar

\begin{tabular}{cc}
\hline Kategori & Frekuensi N-Gain \\
\hline Tinggi & 2 \\
Sedang & 33 \\
Rendah & 1 \\
Kategori rata-rata & 0,49 \\
Jumlah siswa & 36 \\
\hline
\end{tabular}

Dari 36 siswa siswa yang memiliki kategori N-Gain tinggi 2 orang, kategori N-Gain sedang berjumlah 33 orang, dan kategori N-Gain rendah berjumlah 1 orang. Sehingga besarnya N-Gain peningkatan hasil belajar siswa kelas eksperimen (X PBKM 1) SMK Negeri 2 Banjar pada mata pelajaran akuntansi dasar dengan menggunakan model pembelajaran konvensional setelah melaksanakan pretest dan posttest bernilai 17,71 dengan rata-rata 0,49 dan termasuk dalam kategori N-Gain sedang atau berada pada interval 0,30 < N-gain $<0,70$.

Meskipun hasil belajar siswa mengalami peningkatan, namun pembelajaran dengan metode konvensional ini tidak dianjurkan karena motode konvensional merupakan metode pembelajaran yang lebih terpusat pada guru sehingga siswa cenderung bersifat pasif dan kurang memperhatikan. Metode konvensional tidak menuntut keaktifan siswa, sehingga ketika proses pembelajaran siswa yang tidak memperhatikan dan banyak yang mengantuk. Akibatnya, hasil belajar siswa kurang optimal.

Pengujian Hipotesis Perbedaan Hasil Belajar Siswa yang Menggunakan Media Audio Visual Jenis Video dengan yang Menggunakan Metode Konvensional pada Pengukuran Akhir (posttest) Kelas Eksperimen dan Kelas Kontrol dalam Mata Pelajaran Akuntansi Dasar Kelas X PBKM SMK Negeri 2 Banjar

Berdasarkan hasil rata-rata postest dari kedua kelas yaitu kelas eksperimen dan kelas kontrol. Nilai rata-rata postest kelas eksperimen adalah 84,31 dengan standar deviasi 4,65. Sedangkan nilai rata-rata kelas kontrol 77,22 dengan standar deviasi 6,59. Dari hasil perhitungan postest kelas eksperimen dan kelas kontrol dengan menggunakan uji-t diperoleh nilai thitung sebesar 5,25 .

Dari hasil perhitungan uji $t$ (t-test) yang dilakukan diperoleh nilai thitung sebesar 5,25 pada $\mathrm{dk}=70$ maka diperoleh $t_{\text {tabel }}$ sebesar 1,67. Maka dapat disimpulkan bahwa thitung $>t_{\text {tabel }}$ atau $5,25>1,67$. Dengan demikian terdapat perbedaan hasil belajar siswa yang menggunakan Media Pembelajaran Audio Visual tipe Video dengan yang menggunakan metode konvensional.

Perbedaan hasil belajar siswa yang menggunakan media pembelajaran audi visual tipe video pada kelas eksperimen di kelas X PBKM 1 memiliki nilai rata-rata posttest lebih tinggi yaitu sebesar 84,31 dibandingkan dengan nilai rata-rata posttest siswa yang menggunakan metode konvensional pada kelas kontrol di kelas X PBKM 2 yaitu sebesar 77,22. Meskipun sama sama mengalami peningkatan, tetapi dilihat dari nilai rata-rata peningkatan hasil belajar yang menggunakan media audio visual tipe video lebih besar.

Media pembelajaran merupakan salah satu hal penting dalam proses belajar mengajar, maka dari itu sebelum memberikan pembelajaran seorang pendidik perlu mempertimbangkan media pembelajaran yang akan digunakan dalam proses pembelajaran. Karena media pembelajaran yang baik dapat mempengaruhi hasil belajar siswa. Selaras dengan pendapat menurut Jalius \& Ambiyar (2016) mengungkapkan bahwa "Penggunaan media dalam kegiatan belajar mengajar memiliki pengaruh yang besar terhadap alat-alat indera, terhadap pemahaman isi pelajaran, secara nalar dapat dikemukakan bahwa dengan penggunaan media akan lebih menjamin terjadinya pemahan yang baik pada siswa". 
Dengan demikian, penggunaan media Audio Visual tipe Video memiliki peran yang positif dan berpengaruh lebih besar dalam meningkatkan hasil belajar siswa dibandingkan dengan menggunakan metode konvensional. Tetapi media Audio Visual tipe Video bukan satu-satunya faktor yang dapat mempengaruhi peningkatan hasil belajar siswa, tetapi peningkatan hasil belajar siswa juga dapat dipengaruhi oleh faktor lain.

\section{KESIMPULAN}

Berdasarkan hasil penelitian dan pembahasan yang penulis sajikan, dapat ditarik beberapa simpulan sebagai berikut:

1. Terdapat peningkatan hasil belajar siswa pada kelas yang menggunakan Media Audio Visual Jenis Video pada pengukuran awal (pretest) dan akhir (post-test)

2. Terdapat peningkatan hasil belajar siswa pada kelas yang menggunakan Metode pembelajaran konvensional pada pengukuran awal (pretest) dan akhir (post-test)

3. Terdapat perbedaan hasil belajar siswa yang menggunakan Media Audio Visual Jenis Video dengan yang menggunakan metode konvensional pada pengukuran akhir (post-test)

\section{REKOMENDASI}

Dalam pembelajaran, media pembelajaran Audio Visual tipe Video bisa menjadi alternatif yang dipilih oleh pendidik dalam menyampaikan materi dan mendukung pembelajaran, penggunaan media ini dapat merangsang siswa untuk berperan aktif serta mempermudah siswa untuk menyerap materi yang diberikan sehingga mampu meningkatkan hasil belajar siswa. Dan bagi yang berminat untuk melakukan penelitian lebih lanjut sebaiknya mempersiapkan segala sesuatunya lebih matang lagi mulai dari pemahaman, alokasi waktu, serta sarana yang menunjang agar hasil yang di dapat bisa maksimal.

\section{UCAPAN TERIMAKASIH}

Peneliti mengucapkan terimakasih kepada bapak Drs. H. Maman Sudirman, MM selaku Kepala SMK Negeri 2 Banjar dan Ibu Rian Rindanti, SE selaku guru Mata Pelajaran Akuntansi Dasar yang telah memperkenankan dan membantu dalam melakukan penelitian. Tak lupa ayah, ibu dan tante tercinta yang senantiasa memberikan dorongan dan motivasi kepada saya sehingga dapat menyelesaikan penelitian ini.

\section{DAFTAR PUSTAKA}

Aryansyah, F. (2021). Pelaksanaan Question Student Have Method Dalam Meningkatkan Hasil Belajar Pada Mata Pelajaran Ekonomi di SMA. J-KIP (Jurnal Keguruan dan IImu Pendidikan), 2 (1), 91-98.

Dimyati \& Mudjiono. (2006). Belajar dan Pembelajaran. Jakarta: Rineka Cipta

Djamarah, S. B., \& Zain, A. (2013). Strategi Belajar Mengajar. Jakarta: Rineka Cipta

Jalius, N., \& Ambiyar. (2016). Media dan Sumber Pembelajaran. Jakarta: Kencana.

Putri, R. A., Pajiiah, S., \& Kusmayadi, Y. 2021. Kesenian Gembyung Sebagai Media Dalam Pembelajaran Sejarah di SMA Negeri 1 Lumbung Kelas X IPS 1 Tahun Ajaran 2018-2019. J-KIP (Jurnal Keguruan dan IImu Pendidikan). 2 (1), 45-52. 
Simarmata et al. (2020). Elemen-Elemen Multimedia Teks, Gambar, Suara, Video, Animasi Untuk Pembelajaran. Medan: Yayasan Kita Menulis.

Sudjana, N. (2009). Penilaian Hasil Proses Belajar Mengajar. Bandung: PT. Remaja Rosdakarya 